\title{
Comparison of Gamma Irradiated and Raw Lignite in Bioliquefaction Process by Fungus T5
}

\author{
I. Sugoro ${ }^{1,2^{*}}$, D.I. Astuti ${ }^{1}$, D. Sasongko ${ }^{3}$ and P. Aditiawati ${ }^{1}$ \\ ${ }^{1}$ School of Life Science and Technology, Bandung Institute of Technology \\ Jl. Ganesa 10, Bandung 40132, Indonesia \\ ${ }^{2}$ Center for Application of Isotope and Radiation Technology, National Nuclear Energy Agency \\ Jl. Lebak Bulus Raya No. 49, Jakarta, Indonesia \\ ${ }^{3}$ Department of Chemical Engineering, Bandung Institute of Technology \\ Jl. Ganesa 10, Bandung 40132, Indonesia
}

\section{ARTICLE INFO}

Article history:

Received 5 December 2011

Received in Revised form 21 May 2012

Accepted 11 June 2012

Keywords:

Bioliquefaction of coal

Raw lignite

Gamma irradiated

Fungus T5

\begin{abstract}
A B S T R A C T
The bioliquefaction of coal is a processing technology for converting solid coal to liquid oil at ambient temperature by helping microorganism. The pretreated of lignite is important to decrease the hydrofobic of lignite surface. One of pretreated method was irradiation by gamma rays. Aim of this research was to compare the gamma irradiated lignite and raw lignite in bioliquefaction process by selected fungus T5. The fungus was identified by molecular method using $18 \mathrm{~S}$ rDNA. Treatments were A (MSS + gamma irradiated lignite 5\% + T5) and B (MSS + raw lignite $5 \%+\mathrm{T} 5)$ and culture type was sub-merged. The parameters observed were colonization, bacterial and fungal enumeration, identify of dominant bacteria using 16S rDNA and characterization of bioliquefaction product by UV-Vis spectroscopy dan gas chromatography - mass spectrometry (GCMS). The results showed that fungus T5 belongs to Ascomycota, Trichoderma asperellum. Fungus has the ability to growth and liquefy gamma irradiated and raw lignite. Bacteria were detected in raw lignite treatment and dominant bacteria were identified as Bacillus megaterium and Bacillus thuringensis. UV-Vis analysis showed that boliquefaction product mainly contained naphtacene, naphthalene, and anthracene for gamma irradiated lignite, but anthracene and benzene for raw lignite. For GCMS analysis, 22 and 38 compounds were identified for gamma irradiated and raw lignite. Both treatment had different number of hydrocarbon, i.e. $\mathrm{C}_{6}-\mathrm{C}_{35}$ (A) and $\mathrm{C}_{10}-\mathrm{C}_{35}$ (B) and dominated by aromatic acids, aliphatic and phenylethers. Percent area of gasoline $\left(\mathrm{C}_{7}-\mathrm{C}_{11}\right)$ and diesel $\left(\mathrm{C}_{10}-\mathrm{C}_{24}\right)$ fractions on the treatment $\mathrm{B}$ was $7.23 \%$ and $62.35 \%$, while in treatment A was $7.22 \%$ and $44.27 \%$. Based on the results, pretreated of lignite by gamma irradiation could be increased the bioliquefaction product.
\end{abstract}

(C) 2012 Atom Indonesia. All rights reserved

\section{INTRODUCTION}

Coal has been known for its ability to provide energy. It is available in bulk and relatively cheaper in term of extraction than oil. But coal has its own weakness. In the world, coal is mostly available as low quality coal. About $47 \%$ of total world coal reserves are low quality coal (World Coal Institute, 2009). Indonesia, as a country which owns $0.52 \%$ of the world total coal reserves, has $49 \%$ of low quality coal from total [1]. By the end of 2010, proved recoverable reverses of Indonesia coal was 11.7 billion tons, accounting for more than $5 \%$ of total coal reserve in world [2].

\footnotetext{
* Corresponding author.

E-mail address: irawans@batan.go.id
}

In coal classification according to rank, the low quality coal is classified under lignite and subbituminous rank. The lignite and sub-bituminous coals have high amount of moisture and volatile matter and low amount of fixed carbon. This means they are low in calorific value thus producing low energy which makes them unperformed in industrial application [3]. Many ways have been tried to improve the quality and competitiveness of these low rank coals. One of the ways is liquefaction. Low rank coal liquefaction can be done thermally and biologically [4]. Thermal liquefaction, though is used in industry often, has several disadvantages. Thermal liquefaction consumes high energy due to its high temperature and pressure process and needs big operational cost because of the complexity in installation [5]. Part of the heat that is needed in thermal liquefaction process is coming from the combustion of the coal itself. Another disadvantage of thermal liquefaction process is its 
emission of $\mathrm{CO}_{2}$ gas that contributes to global warming and environmental problems. Because of those reasons, some experts in the world try to change the method for low rank coal liquefaction by using biological method.

Studies about bioliquefaction of low rank coal have been conducted by many researchers. There are many scopes of work in the studies. For example, some researchers have studied bioliquefaction of low rank coals by different fungus like filamentous fungi, streptomycetes, Trichoderma atroviride, and several bacterial strains like Pseudomonas and Rhodococcus [6]. Other research studies the mechanism of bioliquefaction including secretion of alkaline substances, oxidative enzymes, chelators, esterase and hydrolytic enzymes [7]. The other researcher scope is optimization of several process parameters like effects of different carbon and nitrogen source, chelator and metal ions in bioliquefaction [8]. Bioliquefaction rate could be increased by pre-treatment of lignite i.e. irradiated by gamma rays and oxidized by nitric acid [9]. Recent study by Sugoro et.al. reveals that an indigenous fungi isolate (code: T5) has potency as bioliquefaction agent [10].

The main objective of this research is to comparasion the gamma irradiated and raw lignite in bioliquefaction process and characterizes the liquid product. The doses of gamma irradiated was $20 \mathrm{kGy}$ to sterilize lignite. The raw lignite will be used as control. The advantage of raw lignite is the apparent of indigenous microbial and maybe could be made consortium with fungus T5. In this study, we also would characterize fungus $\mathrm{T} 5$ by $18 \mathrm{~S}$ rDNA, bacterial and fungal enumeration, identify of dominant bacteria using $16 \mathrm{~S}$ rDNA and then liquefied lignite will be characterized using UV-Vis and GCMS.

\section{EXPERIMENTAL METHODS}

\section{Lignite and pretreatments}

Fresh lignite was sampled from Tanjung Enim - South Sumatera and ground to small particles with $\leq 100$ mesh in a grinding mill. These small lignite particles were irradiated by gamma rays at $20 \mathrm{kGy}$ doses then were kept in a refrigerator at $4^{\circ} \mathrm{C}$, before being used for bio-liquefaction tests.

\section{Molecular identification of fungus T5}

The genomic DNA of fungus T5 was extracted using genomic DNA purification Kit (Biogen fungus gene extraction kit) according to the manufacturer's instructions and the 18S rDNA gene was amplified by PCR using the universal 18S rDNA primers : (5'-TCCTCCGCTTATTGATATGC-3') and reverse primers : (3'-CCGCAGGTTCACCTACGGA-5'). The 18S rDNA gene sequence was comparatively analyzed with the nucleic acid database of Genbank [11].

\section{Procedure of lignite bioliquefaction}

Method was submerged culture and the treatments were A (MSS + gamma irradiated lignite $5 \%+\mathrm{T} 5$ ) and $\mathrm{B}$ (MSS + raw lignite $5 \%+\mathrm{T} 5$ ). Cultures were incubated at room temperature and agitated at $120 \mathrm{rpm}$ for 28 days. Parameters observed were colonization, bacterial and fungal enumeration, identify of dominant bacteria using $16 \mathrm{~S}$ rDNA and characterized of bioliquefaction product. Bioliquefaction product was analyzed only after 21 days incubation [10].

\section{Chemical analysis of bioliquefaction products}

Culture sample was centrifuged at $5400 \mathrm{rpm}$ for 30 minutes. The supernatant was scanned with light wave length from $200 \mathrm{~nm}$ to $600 \mathrm{~nm}$ using a spectrophotometer UV-Vis. The supernatant of culture sample was added with solvent with 1:1 ratio. Solvent is a solution of benzene, hexane and diethyl ether with 3:1:1 ratio. The solution of supernatant and solvent was stirred and settled until upper and lower phase are created. The upper phase was analyzed with GCMS.

\section{RESULTS AND DISCUSSION}

\section{S rDNA analysis of fungus $\mathrm{AH}$}

18S rDNA of fungus T5 was studied. By searching and comparing this sequence in Gene Bank in NCBI, the fungus matched results showed that this microorganism has been discovered by Chinese, German and Turkiye. Other researchers also isolated it from woody samples. It indicated that some lignin decomposing microorganisms can liquefy lignite [4]. Further by comparing DNA sequence, it was found that fungus $\mathrm{T} 5$ belongs to Ascomycota, Trichoderma asperellum. Below is the DNA sequence of this microorganism: 


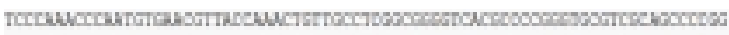

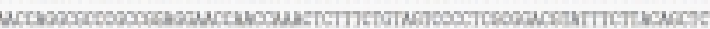

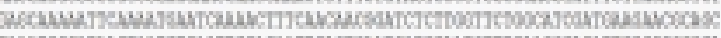

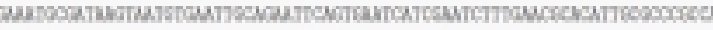

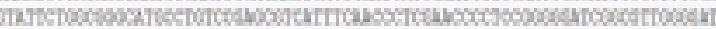

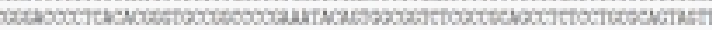

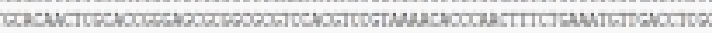
NTCasctave

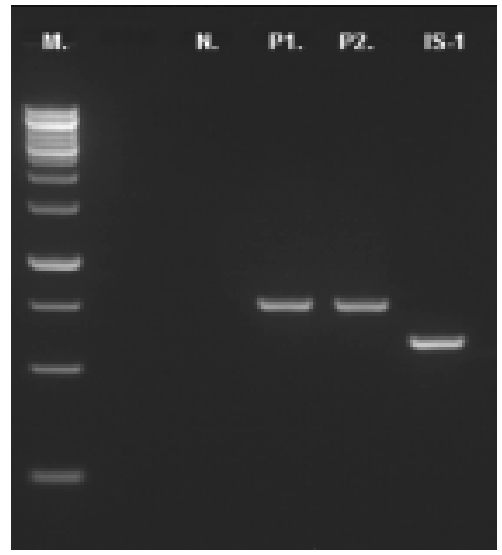

Fig. 1. DNA isolation of fungus T5 $\mathrm{M}$. DNA ladder; N. Negative control; P1. Positive Control 1; P2. Positive Control 2; IS-1.

The genus of Trichoderma usually use as coal bioliquefaction agent, i.e. Trichoderma atroviride. It needed more than 40 days to liquefy $9.3 \%$ of lignite by using $T$. atroviride in a $25 \mathrm{~L}$ bioreactor and 60 days to liquefy $90 \%$ of lignite in the surface culture [4]. The use of Trichoderma asperellun as bioliquefaction agents no one has reported.

\section{Fungi and bacteria population}

Fungi could be growth in gamma irradiated (A) and raw (B) lignite, but had different growth rate (Table 1). Fungi could be growth in gamma irradiated lignite better than raw lignite and showed from mycelia colonization (Fig. 2). Pretreated by gamma irradiated made the lignite surface more hydrophilic. Colonization is one of fungus strategy to contact directly with coal surface. The enzyme will be released and linked at miselia surface. Besides that, irradiated could be broken the complex bounds of lignite and increased the site adsorption of cells or enzymes [9]. It makes, the growth of micellia is higher than the raw lignite.

Table 1. Population of fungi

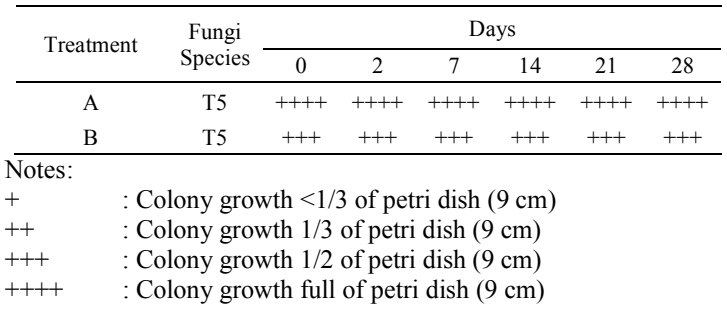

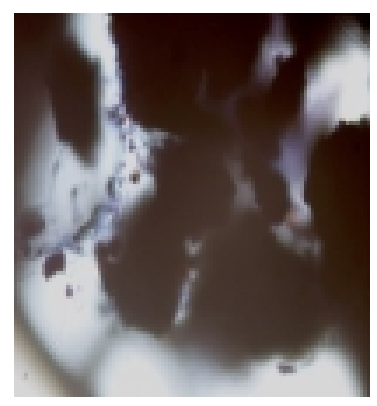

A

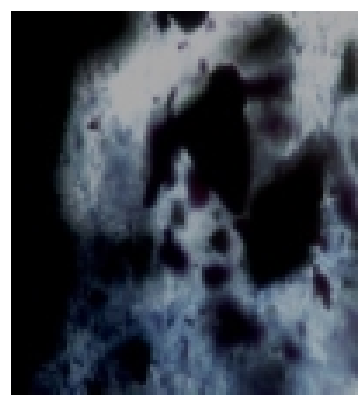

$\mathbf{B}$
Fig. 2. Fungi colonization on lignite surface after 21 days incubation (A : gamma irradiated lignite and B (raw lignite).

The other hand, raw lignite was contained indigenous microbial, such as bacteria and inhibited the fungi growth. The total number of bacteria lignite was $3.5 \times 10^{5} \mathrm{CFU} / \mathrm{g}$. Bacteria could be growth only in $\mathrm{B}$ treatment, because the raw lignite contains dormant bacteria (Fig. 3A). The gamma irradiation could be killed the bacteria in lignite. The enumeration showed that the bacteria growth was increased until 21 days incubation. The fungi and bacteria could growth together and could be made a consortium pattern. The medium contained saccharose as co-substrate before the microbial utilized lignite as main substrate. Eight bacteria has detected in B treatment, i.e. BM04, BM21, BM01, BMT01, BM02, BMT24, BM23, and BMT71 (Fig. 3B).
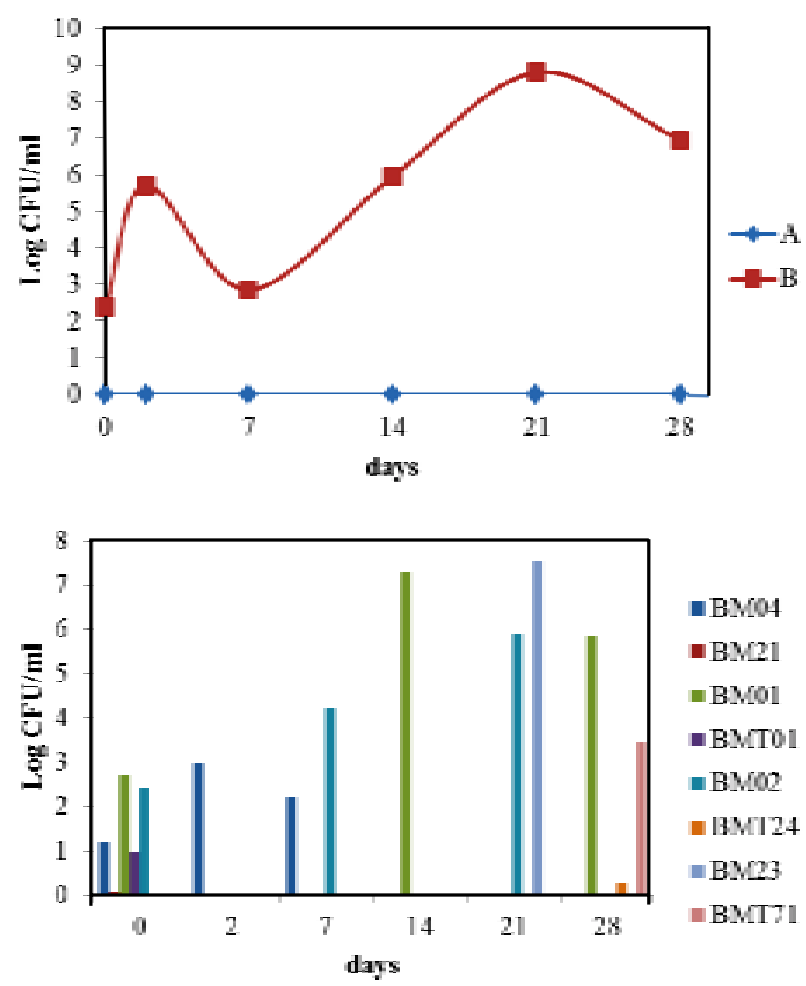

Fig. 3. Enumeration of bacterial (above) and dynamic of bacterial population (below) (A : gamma irradiated lignite; B : raw lignite). 


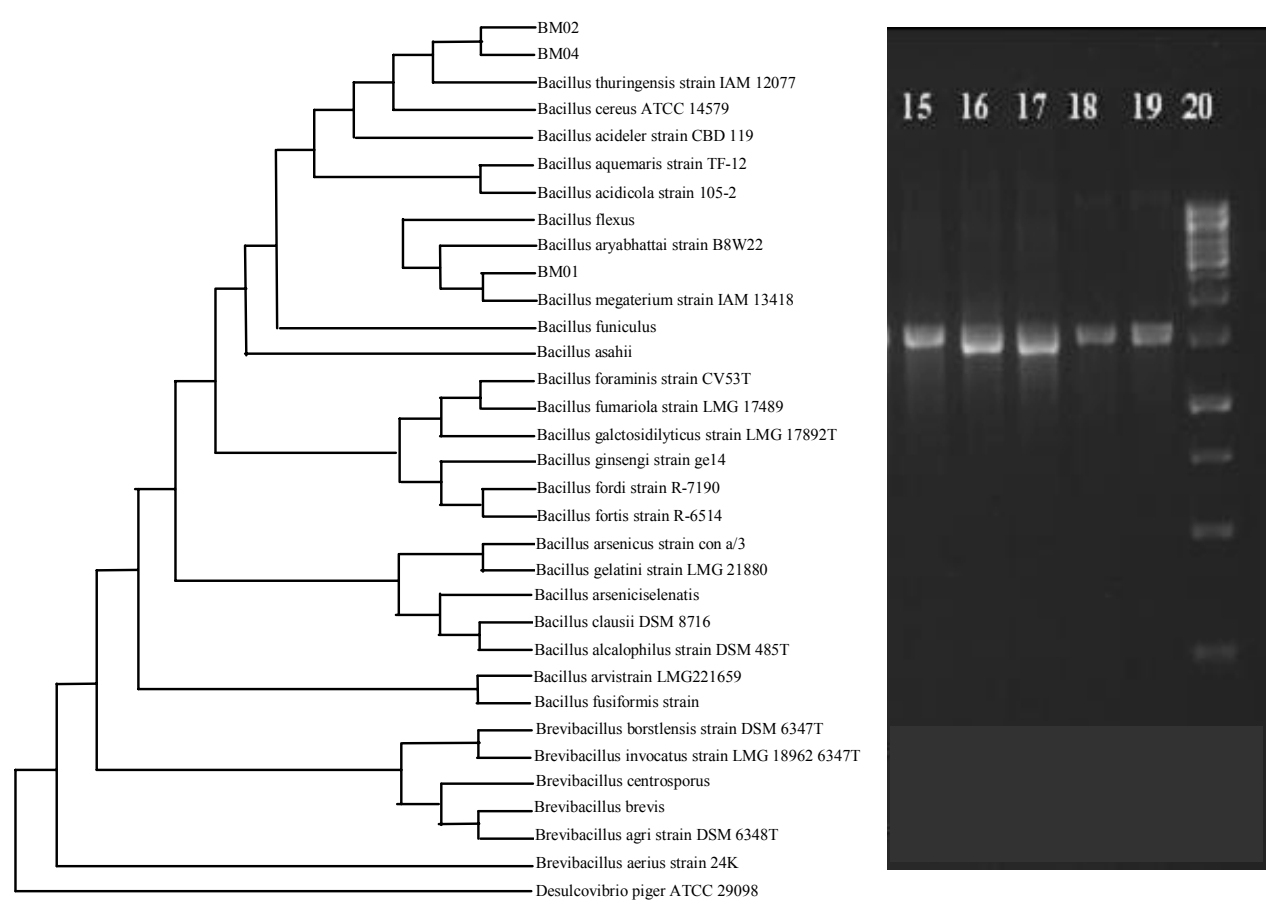

Fig. 4. The identification result of three bacteria dominant by $16 \mathrm{~S}$ rDNA.

Generally, the bacteria cell morphology was bacilli. Population dominancy was different for each day, because the complexity and heterogeneity of lignite compound. Each bacterium utilized the different carbon sources from lignite. The highest apparent occurred on isolate BM01, followed by BM02 and BM04. A dominant bacterium was identified by $16 \mathrm{~S}$ rDNA. Further by comparing DNA sequence, it was found that BM01 belong to Bacillus megaterium and BM02 and BM04 belong to Bacillus thuringensis (Fig. 4). Both bacteria have the ability to dormancy as spore [8]. Other researchers also used the bacteria as lignite liquefy agent [12].

Based on the result, we could be analysis that pretreated of gamma irradiated will be resulted different product compare raw lignite, because bioliquefaction process was involved only one microbial, i.e. T. asperellum. The bioliquefaction of raw lignite was involved more microbial such as bacteria and $T$. asperellum. The single culture has the advantage, which is the product will be same generally and could be controlled easier [7].

\section{Ultraviolet-visible spectrum of bioliquefaction product}

The result of UV spectroscopy of liquefaction product was shown in Fig. 5. Both treatment have different pattern after 21 days incubation. There were three peaks for gamma irradiated which showed the existence of naphtacene, naphthalene and anthracene. The major absorbance in

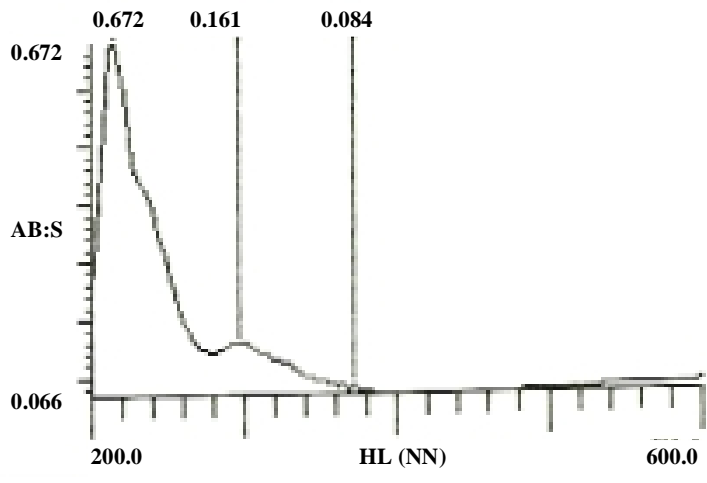

A

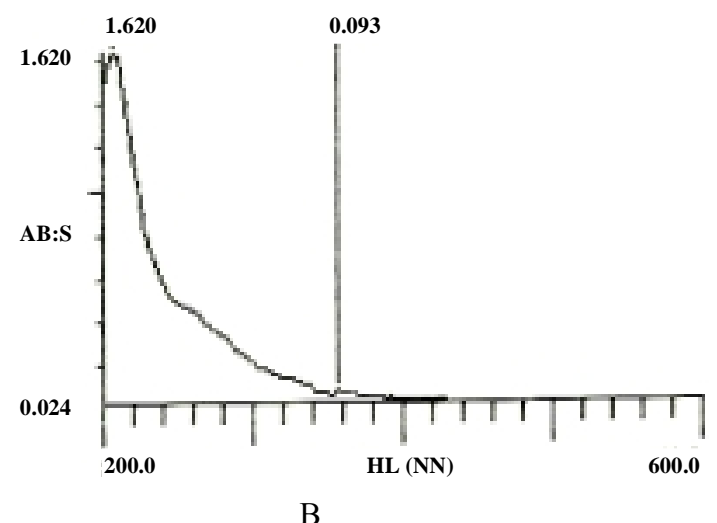

Fig. 5. UV-Vis spectrums of bioliquefaction product (A : gamma irradiated lignite; B : raw lignite). 
the range $200-300 \mathrm{~nm}$ indicates that unsaturated chemical bonds exist in liquefaction products [13]. In particular, absorbance in the $260-300$ $\mathrm{nm}$ range indicates that aromatic structure existed in liquefaction product [11]. The aromatic ring is the main structure unit of lignite. Lost of aromatic ring unit, are connected by complex cross links, that made lignite exist as solid. But after bioliquefaction, aromatic structure were found in product, indicating the isolated fungus could break some cross links in lignite so that the simple aromatics ring were released from lignite to media.

\section{Gas chromatography-mass spectrometry (GCMS) of bioliquefaction product}

The result of the GCMS spectrometry of bioliquefaction product is presented in Fig.6. There were over 22 and 38 component for gamma irradiated and raw lignite detected from the GC-MS results. From the molecular formulas, their carbon numbers $\left(\mathrm{C}_{6}-\mathrm{C}_{35}\right.$ for $\mathrm{A}$ and $\mathrm{C}_{10}-$ $\mathrm{C}_{35}$ for $\mathrm{B}$ ) were much smaller than that typical coal $\left(\mathrm{C}_{661}\right)$ [14]. The differences showed that there was an influenced of indigenous microbes to raw lignite process, resulting much more detected compound. The products were dominated by aromatic acids, aliphatic and phenylethers. From $\mathrm{A}$ and $\mathrm{B}$ treatment, the highest concentration and carbon chain was 2,6-di-tert-butyl-4-[(2octadecyloxycarbonyl)ethyl]-fenol $\left(\mathrm{C}_{35} \mathrm{H}_{62} \mathrm{O}_{3}\right)$, i.e. 50.93 and $55.33 \%$ area. That compound was the most heavy chain bioliquefaction products. The lowest chain of A's treatment was naphthalene $\left(\mathrm{C}_{10} \mathrm{H}_{8}\right) \quad 4.06 \%$ area and $\mathrm{B}$ 's was 1cyclohexyeicosane $\left(\mathrm{C}_{6} \mathrm{H}_{11}\right) \quad 0.60 \%$ area. Percent area of gasoline $\left(\mathrm{C}_{7}-\mathrm{C}_{11}\right)$ and diesel $\left(\mathrm{C}_{10}-\mathrm{C}_{24}\right)$ fractions on the treatment $\mathrm{B}$ was $7.23 \%$ and $62.35 \%$, while in treatment $\mathrm{A}$ was $7.22 \%$ and $44.27 \%$.

Bioliquefaction products had lower molecular weight and smaller structure than typical coal. There were some dominated products i.e. aromatic acid, aliphatic, ester phenyls. Yin et al. [15] showed a smaller carbon chain bioliquefaction product than our research. The differences could be caused by using different microbes and typical coal. From both researches, there were same types of dominated products i.e. aromatic acid, aliphatic, ester phenyl. From this research, bioliquefaction products that resulted from both treatments could be used as oil substitute. There were some products still contained oxygen, which made lower caloric value. Deoxygenated was needed to increase the caloric value.
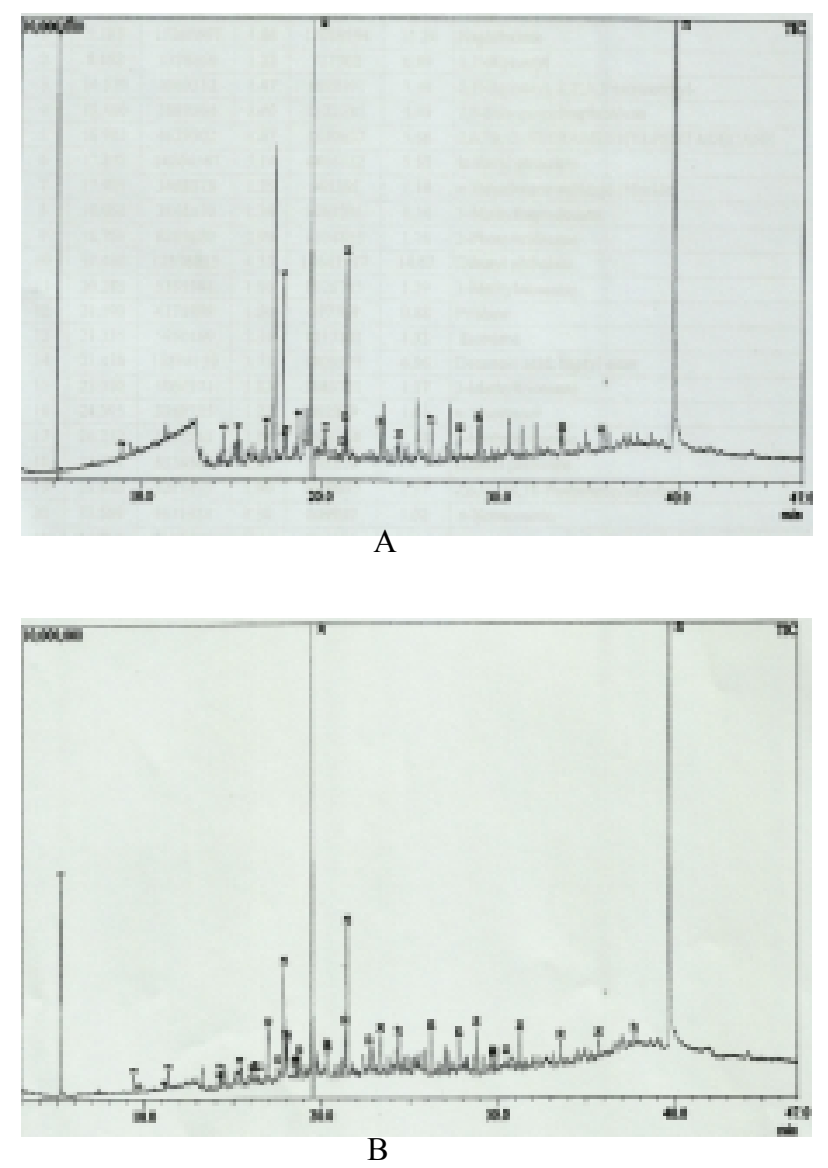

Fig. 6. Chromatogram of bioliquefaction product. (A : gamma irradiated lignite; B : raw lignite).

\section{CONCLUSION}

Fungus T5 showed the ability to growth and liquefy gamma irradiated and raw lignite. 18S rDNA analysis revealed that fungus $\mathrm{AH}$ belongs to Ascomycota, Trichoderma asperellum. Bacteria were detected in raw lignite treatment and dominant bacteria were identified as Bacillus megaterium and Bacillus thuringensis. UV-Vis analysis showed that main components of bio-liquefied lignite (supernatant) were naphthalene and anthracene. For GCMS analysis, 22 and 38 compounds were identified for gamma irradiated and raw lignite. Both treatment had different number of hydrocarbon, i.e. $\mathrm{C}_{6}-\mathrm{C}_{35}(\mathrm{~A})$ and $\mathrm{C}_{10}-\mathrm{C}_{35}$ (B) and dominated by aromatic acids, aliphatic and phenylethers. Percent area of gasoline $\left(\mathrm{C}_{7}-\mathrm{C}_{11}\right)$ and diesel $\left(\mathrm{C}_{10}-\mathrm{C}_{24}\right)$ fractions on the treatment $\mathrm{B}$ was $7.23 \%$ and $62.35 \%$, while in treatment $\mathrm{A}$ was $7.22 \%$ and $44.27 \%$. Pretreated of lignite by gamma irradiation could be increased the bioliquefaction product and could be used as oil substitute. 


\section{ACKNOWLEDGEMENTS}

Thanks to Education and Cultural Ministry for Stranas Grant 2011 and Center for Application of Isotope and Radiation Technology - National Nuclear Energy Agency (BATAN) for radiator facility.

\section{REFERENCES}

1. R. Indrayuda, Indonesian Coal Policy: Prospect and Implementation, APEC Clean Fossil Energy Technical and Policy Seminar, Philippines (2005).

2. ESDM, Indonesia Energy Outlook 2011 (2011).

3. J.G. Speight, Handbook of Coal Analysis, John Wiley and Sons, Inc., New Jersey (2005).

4. K.Y. Shi, X. Tao, S. Yin, Du Ying and Lv Zuo-peng, Bioliquefaction of Fushun Lignite: characterization of newly isolated lignite liquefying fungus \& liquefaction products. The $6^{\text {th }}$ International Conference on Mining Science \& Tech. Procedia earth \& Planetary Science (2009) 627.

5. H. Yoshida, Coal Liquefaction Pilot Plant, New Energy \& Industrial Technology Development Organization, Tokyo (2007).
6. R.M. Fakoussa and P.J. Frost, Appl. Microbiol. Biotechnol. 52 (1999) 60.

7. A.P. Selvi, R.B. Banerjee, L.C. Ram and G. Singh, World J. Microbiol. Biotechnol. 25 (2009) 1713.

8. S.M. Cohen, B.W. Wilson and R.M. Bean. Enzymatic solubilization of coal, in: Wise, L.D. (editor). Bioprocessing dan Biotreatment of Coal, Marcel Dekker Inc., New York (1990).

9. P. Aditiawati, I. Sugoro, D. Indriani and D. Sasongko, A Scientic Journal for the Application of Isotopes and Radiation 1 (2011) 44. (In Indonesia).

10. I. Sugoro, D. Indriani, D. Sasongko and P. Aditiawati, J. Indonesia Biol. Soc. 7 (2011) 299. (In Indonesian).

11. S. Yin, T. Xiuxiang, S. Kaiyi and T. Zhongchao, Energy 34 (2009) 775.

12. R.M. Fakoussa and P.J. Frost, Appl. Microbiol. Biotechnol. 52 (1999) 60.

13. H.D. Schindler, Coal liquefaction : a research needs assessment technical background (1989).

14. J.G. Speight, The Chemistry and Technology of Coal, Marcel Dekker, Inc., New York (1994).

15. K.Y. Shi, X. Tao, S. Yin, Du Ying and Lv Zuopeng, Bio-solubilization of Fushun lignite, The $6^{\text {th }}$ Proceeding Conference on Mining Science \& Technology in Procedia Earth and Planetary Science (2009) 627. 